\title{
Southern Highbush Blueberry Cultivars from the University of Florida ${ }^{1}$
}

\author{
J. G. Williamson, D. A. Phillips, P. M. Lyrene, and P. R. Munoz
}

\section{Introduction}

Blueberries are native to eastern North America and are one of the few crop plants that originated here. The woods and swamps of Florida are populated with at least eight wild blueberry species, including the highbush blueberry (Vaccinium corymbosum), the rabbiteye blueberry (Vaccinium virgatum), and the evergreen blueberry (Vaccinium darrowii). No area of the state lacks wild blueberries, except where soil $\mathrm{pH}$ is above 6.0.

Efforts to breed new blueberry cultivars that were adapted to Florida's mild winter climate and would ripen in April and May began in the 1950s under the direction of Professor Ralph Sharpe at the University of Florida. By crossing northern highbush cultivars with Vaccinium species found throughout Florida and the southeastern United States, Sharpe developed a new type of blueberry known as the southern highbush. Southern highbush blueberries combine the fruit quality and productivity of highbush blueberries with the low chilling requirement necessary to produce a crop in the Florida climate. In 1976 and 1977, the University of Florida blueberry breeding program released three southern highbush blueberry varieties ('Sharpblue', 'Flordablue', and 'Avonblue') that were bred specifically for Florida's mild climate and showed promise for producing early-ripening, high-quality fruit. By 1983, a small blueberry shipping industry was established in Florida. Because these southern highbush blueberries ripened earlier than blueberries from other areas, they brought very high prices. High prices and ready markets have led to the expansion of Florida's bearing blueberry acreage. Between 1982 and 2015, Florida blueberry acreage has increased from less than 1,000 acres to over 5,500 acres, and additional plantings are anticipated. During the 1980s and early 1990s, more than half of the Florida blueberry acreage consisted of rabbiteye varieties. Beginning in the early to mid-1990s, most new blueberry plantings in Florida consisted of southern highbush. Currently, with the exception of small U-pick farms, Florida's blueberry acreage is comprised almost entirely of southern highbush varieties mostly developed by the University of Florida breeding program.

As many new southern highbush plantings have come into bearing, annual statewide blueberry production has steadily increased from about 1.5 million pounds in the early 1990s to over 25 million pounds in 2015. Fresh fruit prices have remained high relative to other US states for early ripening southern highbush varieties. However, production problems have been numerous and severe. Although many aspects of blueberry growing in Florida are better understood than they were in the 1990s, blueberries remain a difficult crop to grow in Florida. Very early flowering makes southern highbush blueberries quite susceptible to late winter/early spring freezes. Southern highbush blueberry plantings without overhead irrigation for frost protection

1. This document is HS1245, one of a series of the Horticultural Sciences Department, UF/IFAS Extension. Original publication date March 2014. Revised February 2019. Visit the EDIS website at https://edis.ifas.ufl.edu for the currently supported version of this publication. J. W. Olmstead and G. K. England contributed to earlier versions of this publication.

2. J. G. Williamson, professor; D. A. Phillips, blueberry Extension coordinator, Gulf Coast Research and Education Center; P. M. Lyrene, professor emeritus; P. R. Munoz, assistant professor, Horticultural Sciences Department; UF/IFAS Extension, Gainesville, FL 32611.

The Institute of Food and Agricultural Sciences (IFAS) is an Equal Opportunity Institution authorized to provide research, educational information and other services only to individuals and institutions that function with non-discrimination with respect to race, creed, color, religion, age, disability, sex, sexual orientation, marital status, national origin, political opinions or affiliations. For more information on obtaining other UF/IFAS Extension publications, contact your county's UF/IFAS Extension office. 
frequently lose their crops as far south as Highlands County. Recently, new diseases such as necrotic ring blotch, bacterial leaf scorch, and bacterial wilt have been observed in commercial blueberry plantings in Florida. Although potentially profitable, blueberry fields can be expensive to establish. Prospective southern highbush growers should be aware of establishment costs, such as overhead irrigation for freeze protection, and large quantities of soil amendments, such as pine bark, that are necessary to improve $\mathrm{pH}$ and organic matter content. Further information on blueberry establishment and production costs can be found at https:// edis.ifas.ufl.edu/fe1002.

The major incentive for growing blueberries in Florida is the excellent market window available for blueberries that ripen before May 15. In recent years, blueberries have been planted in the Southern Hemisphere for shipping to the Northern Hemisphere from November to March. Southern highbush blueberries are being planted in south Georgia and along the Gulf Coast to east Texas, and in California and Mexico. Nevertheless, the market period from April 1 to May 10 is still available to Florida growers, and fruit prices are usually profitable until early to mid-May, when harvest of the Georgia and North Carolina crops rapidly increase market volumes. In recent years, there has been an increase in importation of blueberries from Mexico during this market period, which is expected to continue to increase.

Depending on climatic conditions and cultivar, southern highbush blueberries may be grown using the traditional winter-dormancy production system (which may or may not include use of hydrogen cyanamide), or the "evergreen" or non-dormant system. The evergreen system is sometimes used under conditions of very low winter chilling in central and south-central production areas of Florida, or under tunnels in central and north-central Florida. Only certain cultivars are well-suited for evergreen production (see individual cultivar descriptions). Tunnels represent a substantial increase in production cost. For more information on use of hydrogen cyanamide for traditional winter-dormancy production systems, see EDIS documents "2019 Florida Blueberry Integrated Pest Management Guide" (https://edis.ifas.ufl.edu/pdffiles/HS/HS38000.pdf) and "Reproductive Growth and Development of Blueberry" (https://edis.ifas.ufl.edu/pdffiles/HS/HS22000.pdf).

\section{Cultivars}

Many improved southern highbush cultivars have been developed by the University of Florida breeding program since the initial releases of 'Sharpblue, 'Flordablue', and
'Avonblue' in the mid-1970s. Today, there are more blueberry cultivar choices available for Florida growers than ever before, but in every case, cultivar selection involves weighing the advantages and disadvantages of a cultivar relative to the grower's needs. Unfortunately, there are no perfect cultivars suited for every location and management system. The following discussion categorizes southern highbush cultivars into four groups: (1) major cultivars; (2) secondary cultivars; (3) new cultivar options; (4) cultivars recently approved for release; and (5) historical and obsolete cultivars. Proper cultivar selection is critical to a successful blueberry enterprise, and growers should seek information from multiple sources, including their local UF/IFAS Extension office.

\section{Major Cultivars}

For well over a decade, 'Star,' 'Emerald', and 'Jewel' comprised the backbone of the Florida blueberry industry. While there is a trend toward planting newer cultivars that address specific needs such as increased earliness and the potential for mechanical harvest, a significant portion of planted blueberry acreage in Florida still consists of 'Emerald' and 'Jewel'.

'Emerald' (US Plant Patent 12,165) (Figure 1) was released by the University of Florida in 1999 and is one of the most widely planted cultivars in north-central and central Florida, with smaller plantings in southeast Georgia. 'Emerald' combines a vigorous, upright-spreading bush with high yield potential and large, high-quality berries. 'Emerald' flowers open uniformly, and it produces abundant leaves, but it may benefit from hydrogen cyanamide applications. 'Emerald' has a low enough chill requirement (cool temperature exposure during winter dormancy needed to resume normal growth in the spring) to be adapted to most regions of peninsular Florida where commercial blueberry production occurs. Because the plants are highly vigorous when planted on suitable soils, 'Emerald' is capable of carrying heavy crops and is generally considered one of the highest-yielding cultivars grown in Florida. 'Emerald' normally reaches full bloom in early to mid-February, and overhead irrigation is needed to protect flowers and fruit from freezes in February and March. Fruit clusters are tight and do not ripen uniformly, which makes 'Emerald' more difficult to handpick than many cultivars. 'Emerald' is considered a mid-season cultivar for Florida with an extended harvest season. About $90 \%$ of the fruit of 'Emerald' is normally ripe by May 15 in Gainesville. During heavy production years, fruit prices may decline enough in mid- to late May so that growers make decisions not to harvest the last remaining 'Emerald' fruit. 
'Emerald' is best adapted for planting in north-central and central Florida.

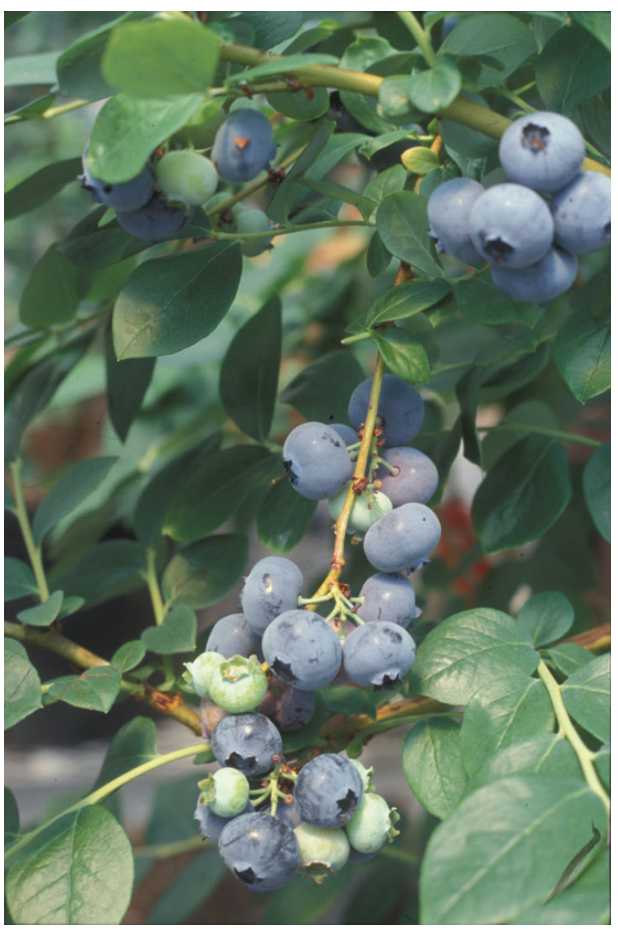

Figure 1.'Emerald'.

Credits: Jeff Williamson, UF/IFAS

'Jewel' (US Plant Patent 11,807) (Figure 2) was released from the University of Florida breeding program in 1998, and it is often planted in combination with 'Emerald' in central and north-central Florida. The plant is upright, vigorous, high-yielding, and survives well in commercial fields. However, 'Jewel' is highly susceptible to blueberry rust leaf spot (Figure 3), and a thorough summer spray program is usually necessary to prevent early fall defoliation. Under low chilling conditions, 'Jewel' is susceptible to injury from hydrogen cyanamide.

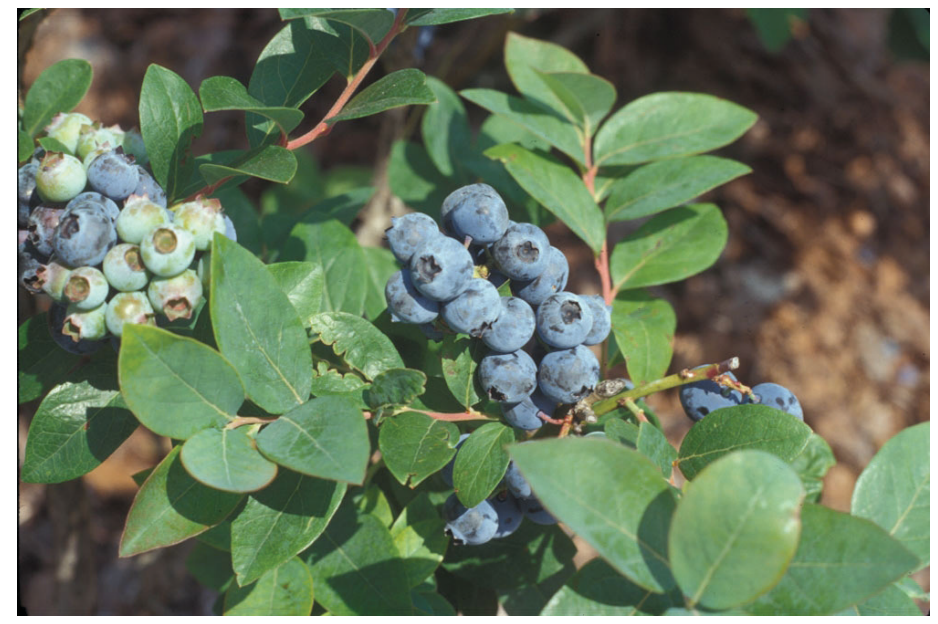

Figure 2. 'Jewel'.

Credits: Jeff Williamson, UF/IFAS

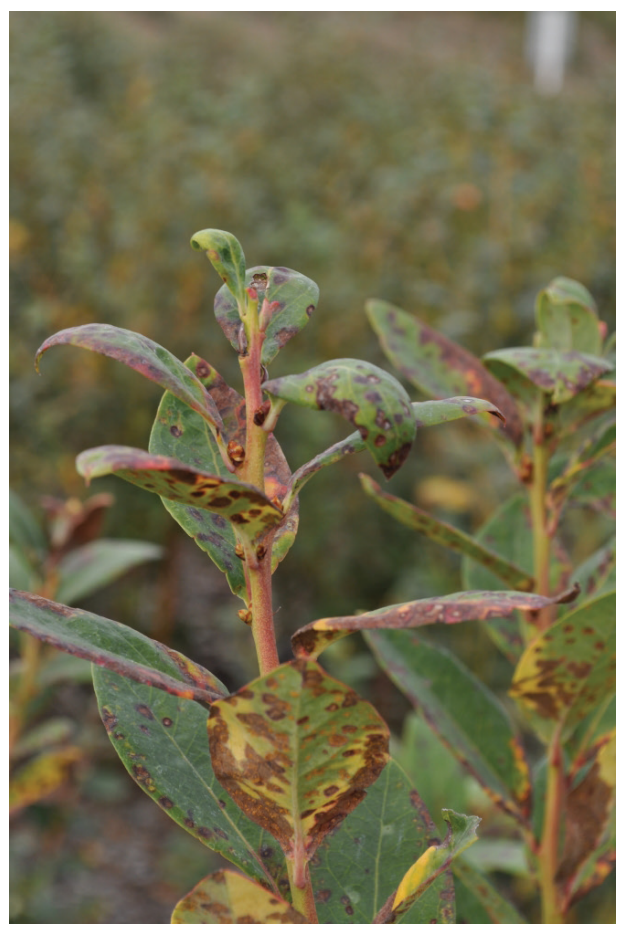

Figure 3. 'Jewel' showing symptoms of rust leaf spot disease. Credits: Jim Olmstead, UF/IFAS

'Jewel' fruit are slightly smaller and softer than 'Emerald', but they are acceptable for commercial packing and shipping. Yield potential is high, and internal berry quality is very good, although berries tend to remain tart until fully ripe. 'Jewel' is considered a mid-season cultivar for Florida. 'Jewel' typically flowers around February 16 in northcentral Florida. The first commercial harvest date is usually before April 10, and harvest is typically finished by May 12 .

'Jewel' is best adapted for planting in north-central and central Florida.

'Farthing' (US Plant Patent 19,341) (Figure 4) was released by the University of Florida in 2007. It is vigorous, with a compact growth habit and numerous branches. Flowering occurs after 'Emerald' and 'Jewel.' 'Farthing' flowers profusely and sets heavy crops with a long harvest season, similar to 'Emerald'. Berry size is usually medium due to heavy crop loads, but can be large with lighter crops. Berry firmness is exceptional, with a nearly crisp texture. Scar and flavor are good. Berry color is darker than average, with below average uniform color development at ripening, due to a tendency for the stem end of the berry to remain red or purple, especially when plants are carrying heavy crops or in tunnel production. Because of its fruit firmness and ability for ripe fruit to persist on the bush longer than average, 'Farthing' has been successfully harvested using machines under commercial production. 
'Farthing' is best adapted for planting in north-central and central Florida.

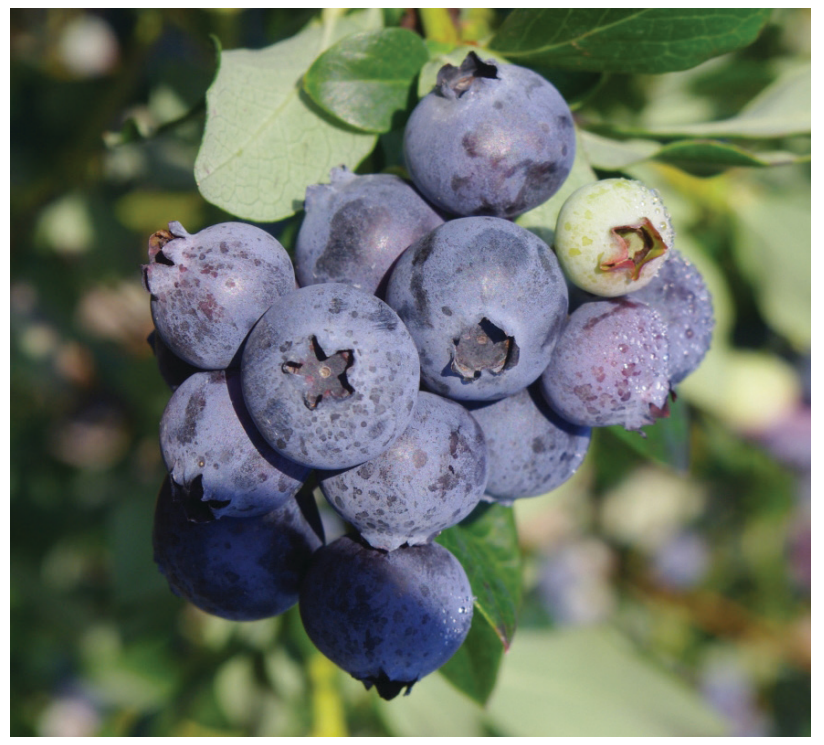

Figure 4. 'Farthing'.

Credits: Jeff Williamson, UF/IFAS

'Meadowlark' ${ }^{\mathrm{TM}}$ (US Plant Patent 21,553) (Figure 5) was released in 2009 by the University of Florida. It is vigorous, with an upright growth habit, a very narrow crown (Figure 6), and the ability to leaf strongly during bloom and carry a heavy crop. Berries ripen very early, with a mean date of mid-April for $50 \%$ ripe berries in Windsor, Florida, when treated with hydrogen cyanamide. Berries are large to medium-large, depending on the crop load, and berry clusters are loose and easy to harvest because of their exceptionally long pedicels and peduncles. Berries have a mild flavor and are somewhat darker than average. Uniform color development at ripening is below average, with a tendency for red or purple color to persist at the stem end while the rest of the berry is fully blue. Berry firmness is very good. Because of its fruit firmness, 'Meadowlark' ${ }^{\text {'M }}$ has been successfully harvested using machines under commercial production.

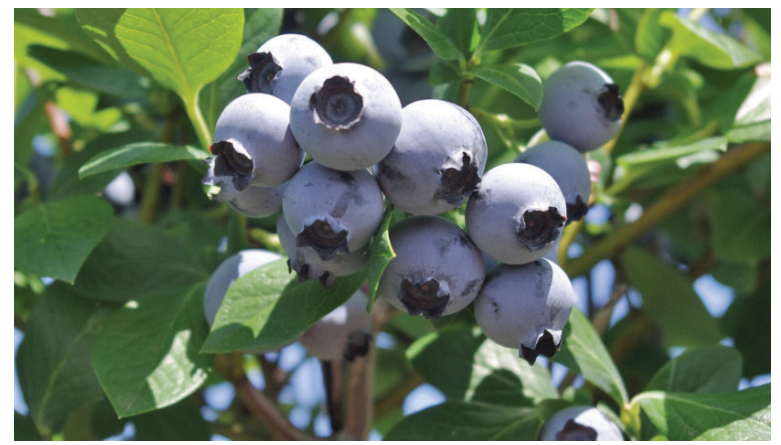

Figure 5. 'Meadowlark ${ }^{\prime \mathrm{m}}$.

Credits: Jim Olmstead, UF/IFAS

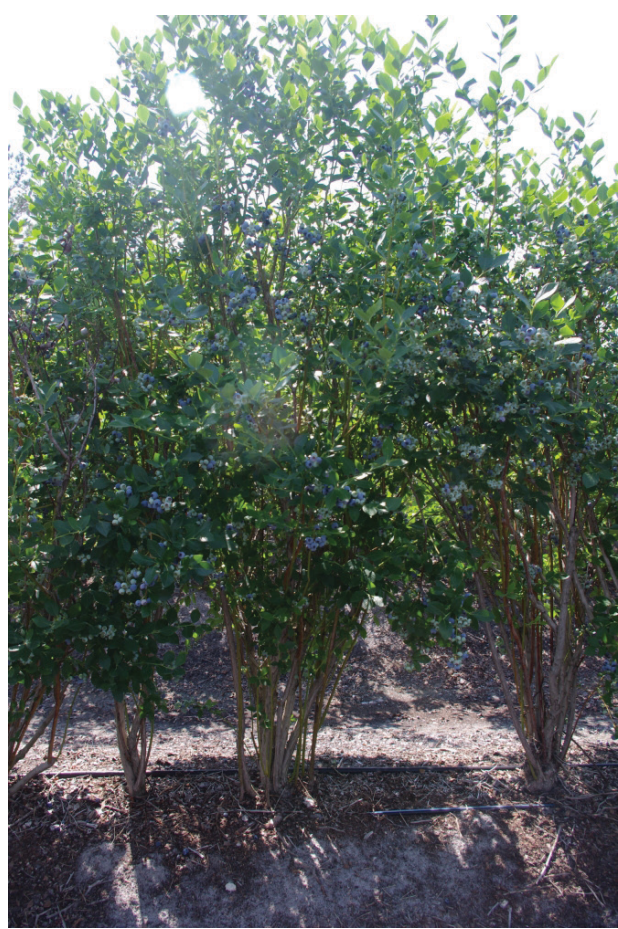

Figure 6. 'Meadowlark' ${ }^{\text {TM }}$ has an upright growth habit. Credits: Jim Olmstead, UF/IFAS

'Meadowlark'тм has greater than average susceptibility to bacterial leaf scorch (Xylella fastidiosa), which is observed more frequently in areas prone to flooding and has resulted in a decline of some plantings in Florida.

'Meadowlark' 'тм is best adapted for planting in north-central and central Florida.

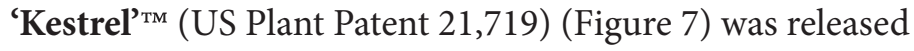
by the University of Florida in 2009. 'Kestrel' ${ }^{\text {тм }}$ is a low-chill cultivar that blooms early and ripens very early. In Windsor, Florida, the mean date of $50 \%$ open flowers is January 30 , and the mean date of $50 \%$ ripe berries is April 22. Berries are medium to large, with excellent flavor and low detachment force. Early leafing and flowering make 'Kestrel' ${ }^{\text {'м }}$ particularly susceptible to late freezes. Berry detachment force is lower than average for blue fruit, which can result in loss of fruit following storms or windy conditions and may limit its potential for machine harvesting. Mite and thrip infestations have been reported on 'Kestrel'тм. Bacterial wilt (Ralstonia solanacearum) was found on 'Kestrel'тм in 2016, and research regarding its susceptibility is ongoing.

'Kestrel' ${ }^{\mathrm{TM}}$ is suggested for trial as evergreen production from Port Charlotte, Florida, to Orlando, Florida, as deciduous production from Tampa, Florida, to Orlando, Florida, and under tunnels in the Gainesville, Florida area. 


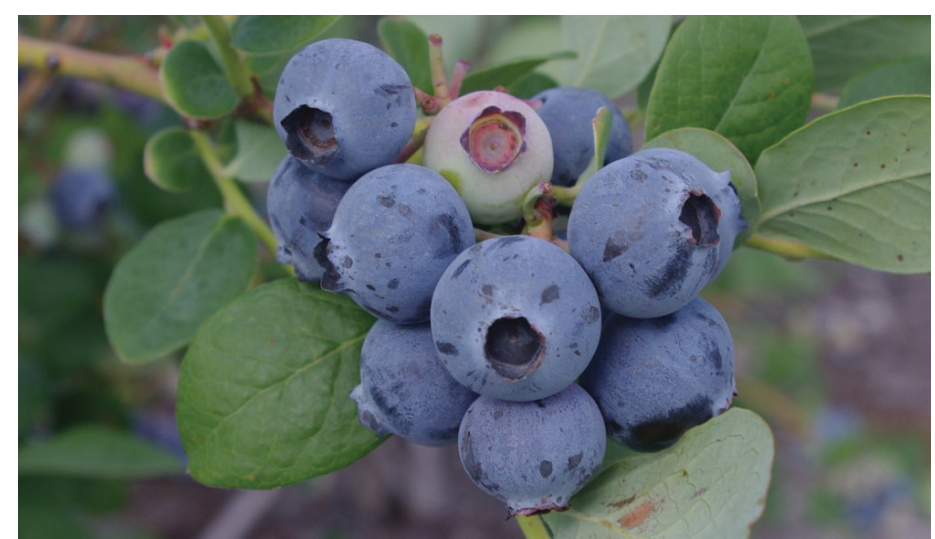

Figure 7. 'Kestrel' ${ }^{\prime \mathrm{m}}$.

Credits: Jim Olmstead, UF/IFAS

'Chickadee' released by the University of Florida in 2009. 'Chickadee'тм is a very early-ripening cultivar with a very low chilling requirement. The plant is upright with stout stems and twigs and has a narrow, almost monopodial base. Due to a weak root system, plants are prone to uprooting from either heavy ice loads during freeze protection or from strong storms. 'Chickadee' ${ }^{\mathrm{TM}}$ does not respond well to heavy pruning. The mean date of $50 \%$ open flowers in Windsor, Florida, is January 28, and the mean date of 50\% ripe berries is April 15. The early bloom requires overhead freeze protection in most areas of Florida. Berries are large and sweet with low acidity and have a firm to semi-crisp texture. Berry quality is maintained on the bush for longer than most other cultivars grown in Florida. Yield potential has been only medium on 'Chickadee'TM, but its low chill requirement and early maturity may find use in central Florida. The bush architecture, fruit firmness, and ability to hold fruit on the bush suggest potential for machine harvesting, but more experience and testing is needed.

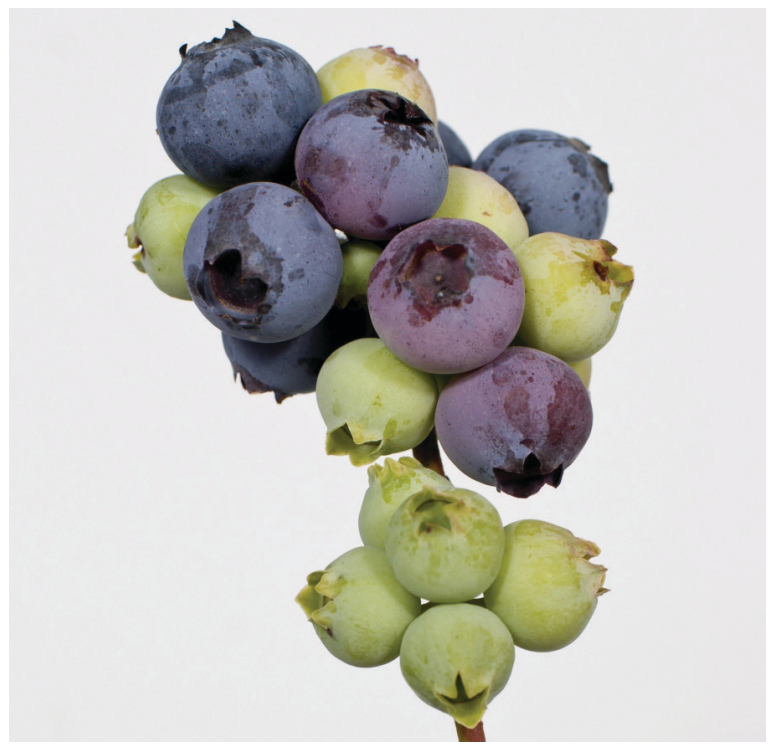

Figure 8. 'Chickadee'TM.

Credits: Jim Olmstead, UF/IFAS
'Chickadee'Tм is suggested for trial in central and southcentral Florida.

'Springhigh' (US Plant Patent 16,476) (Figure 9) was released by the University of Florida in 2004. It is somewhat popular as an earlier-ripening addition to mid-season cultivars such as 'Emerald' and 'Jewel', especially in central and south-central Florida. Fruit are large and have excellent flavor, but they have less waxy bloom, making them appear darker than average, and fruit are softer than most other commercial cultivars. The pack-out for 'Springhigh' has been reduced in some years because of a higher than average incidence of soft berries. Picking at frequent intervals during the harvest season is necessary to minimize the occurrence of soft fruit in packing and grading lines. Some packers may not accept 'Springhigh' fruit due to postharvest quality issues. Before planting 'Springhigh' growers should carefully evaluate the market potential for this cultivar.

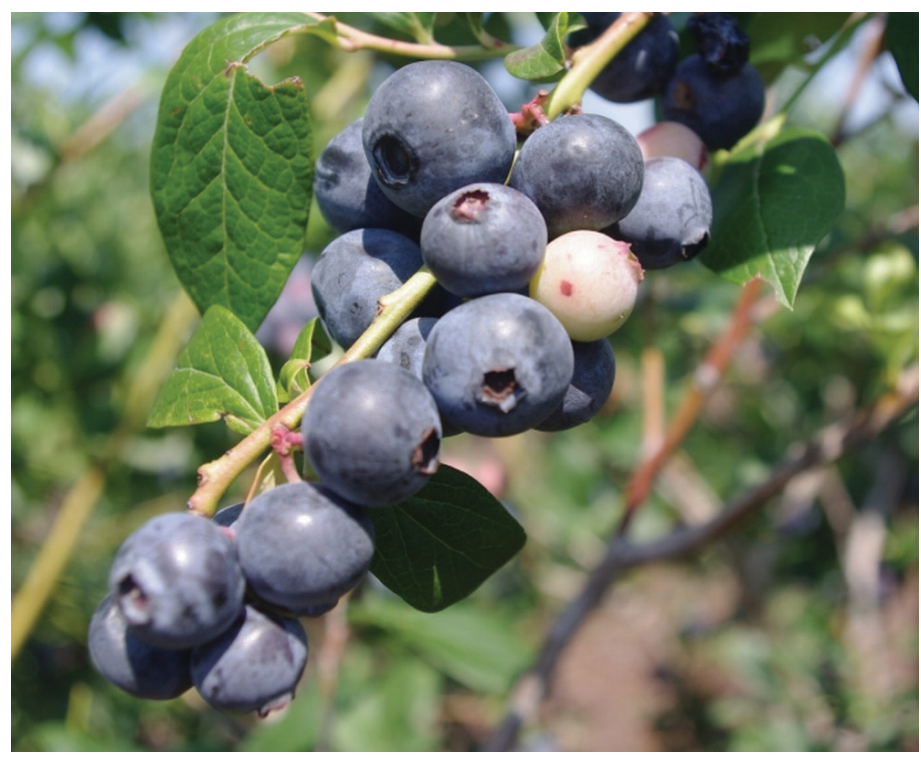

Figure 9. 'Springhigh'.

Credits: Jim Olmstead, UF/IFAS

\section{Secondary Cultivars}

Secondary cultivars are not planted as widely as major cultivars because of limitations for desirable traits such as productivity, fruit quality, fruit size, or earliness. However, they may be useful as a minor component of a cultivar mix under certain conditions.

'Snowchaser' (US Plant Patent 19,503) (Figure 10) was released in 2005 by the University of Florida. It is the earliest-ripening cultivar grown commercially in Florida. 'Snowchaser' has a very low chilling requirement that usually results in early bloom (early to mid-January in Gainesville), making it particularly susceptible to late winter and early spring freezes. Berries usually begin ripening early in 
the season when berry prices are typically high. Thus, very early season production is the main objective when growing this cultivar. 'Snowchaser' produces medium-sized fruit with excellent flavor and good postharvest characteristics. Its field survival is considered marginal because of its susceptibility to stem blight. Snowchaser has been grown by producers in South Florida with varying levels of success. It can be grown in an evergreen system in the right climate, but fruit could be too early for the Florida market window.

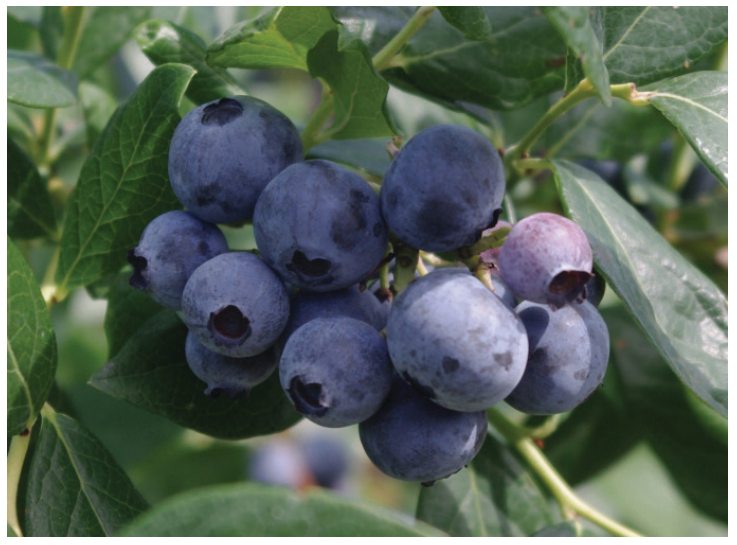

Figure 10. 'Snowchaser'.

Credits: Jim Olmstead, UF/IFAS

'Primadonna' (US Plant Patent 20,181) (Figure 11) was released in 2005 by the University of Florida. It blooms and ripens early. Its berries are large and have excellent flavor. Because of the early maturity and apparent low chilling requirement for the flower buds, 'Primadonna' has been planted in central Florida. In these areas, 'Primadonna' may leaf poorly in some years without the benefit of hydrogen cyanamide. However, hydrogen cyanamide often injures 'Primadonna' flower buds during low-chill winters. 'Primadonna' tends to produce well some years but not others for reasons that defy a clear explanation. Primadonna has been grown by producers in central Florida with different levels of success.

'Sweetcrisp' (US Plant Patent 20,027) (Figure 12) was released by the University of Florida in 2005. 'Sweetcrisp' berries are medium to large and have exceptional firmness, medium blue color, and a remarkably sweet flavor. As the name indicates, 'Sweetcrisp' fruit have a unique crisp texture that has scored favorably in consumer acceptance trials. The postharvest characteristics of the berries are excellent, as is their ability to remain on the bush for extended periods of time without significant loss of quality. Fruit detach easily from the bush and have dry picking scars. 'Sweetcrisp' has shown higher than average potential for mechanical harvesting, although due to low fruit-detachment force, there is a tendency for immature green fruit to detach during mechanical harvesting. Plants survive well in the field but have a vigorous, sprawling growth habit, which makes them somewhat difficult to manage. Yield potential is only medium to low, which is a major reason 'Sweetcrisp' is not widely grown commercially in Florida.

'Sweetcrisp' has a relatively high chilling requirement and is best adapted from Gainesville north into southeast Georgia.

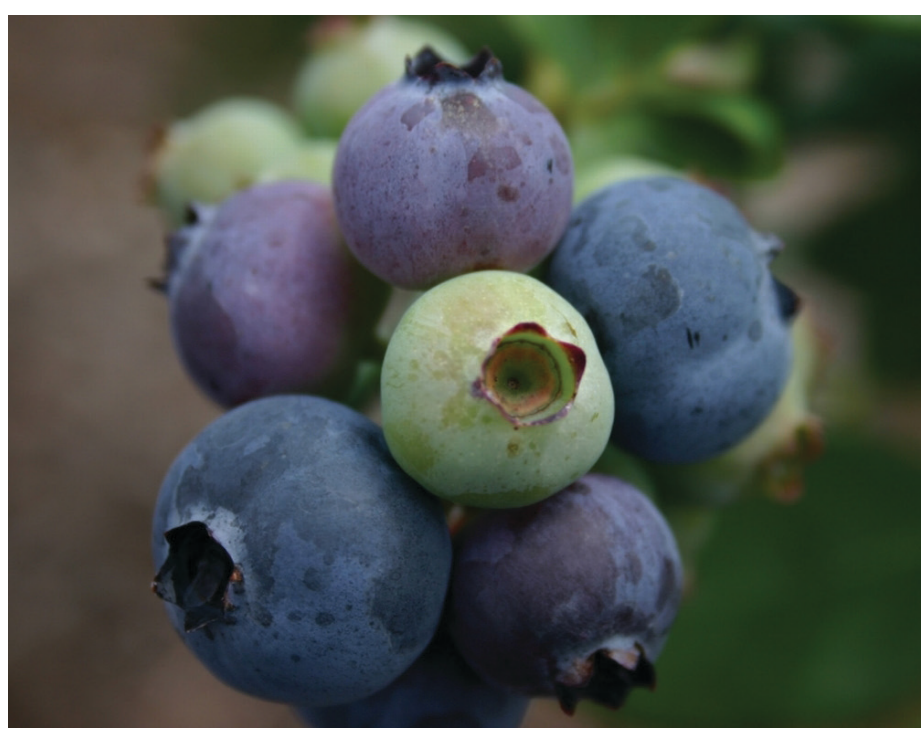

Figure 11.'Primadonna'.

Credits: Jim Olmstead, UF/IFAS

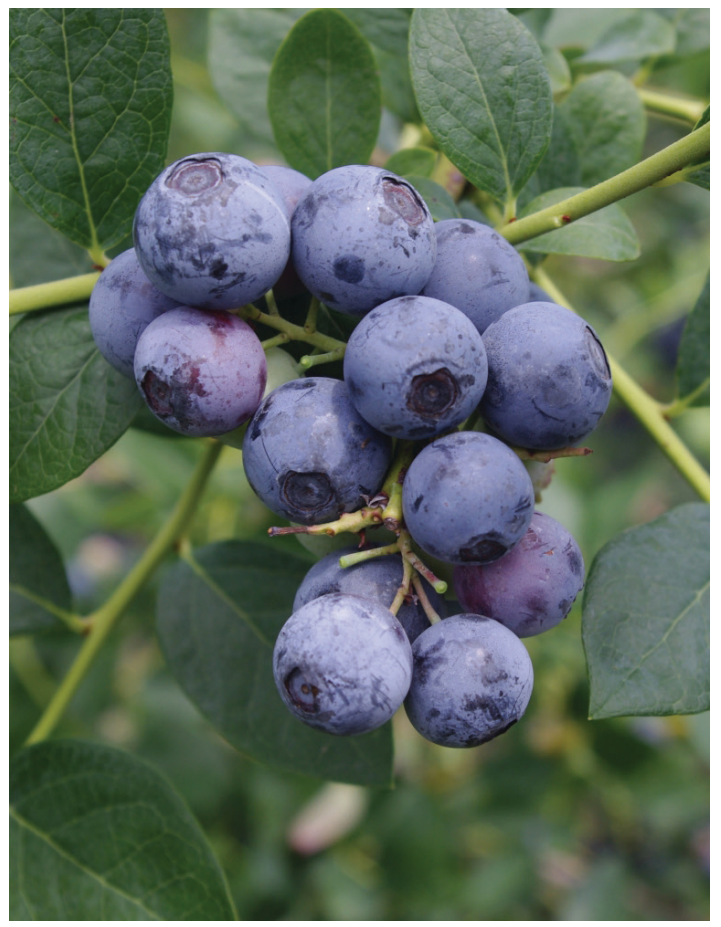

Figure 12. 'Sweetcrisp'.

Credits: Jim Olmstead, UF/IFAS 


\section{New Cultivar Options}

New cultivars are continually being released from the University of Florida blueberry breeding program and are expected to exhibit improvements for certain traits compared to existing cultivars at the time of their release. However, new cultivars have not been observed for as many years and under as many different production systems and conditions as major cultivars. While new cultivars may represent significant improvements for certain traits, growers should proceed cautiously with new cultivars until they gain experience with their performance under a particular management system at their location.

\section{'Arcadia'TM (US Patent 26,313) (Figure 13) is a very} low-chill cultivar released by the University of Florida in 2015. It has high yield in evergreen management systems, with peak production in central and south-central Florida during the high-value market window. The fruit is large with a sweet flavor. Plants have established well in the field and have high tolerance to leaf diseases. In 2016, bacterial wilt (Ralstonia solanacearum) was found on 'Arcadia' ${ }^{\text {'тм }}$ at several locations in Florida. This is a serious disease that can kill plants quickly, and once introduced can spread rapidly throughout a blueberry field. By 2018, Ralstonia had been found in other cultivars as well (not restricted to UF cultivars). Research into the susceptibility of all cultivars is ongoing. Arcadia ${ }^{\mathrm{TM}}$ is still widely planted in south-central Florida because of its high yield.

'Arcadia'Tм is best adapted to central and south-central Florida.

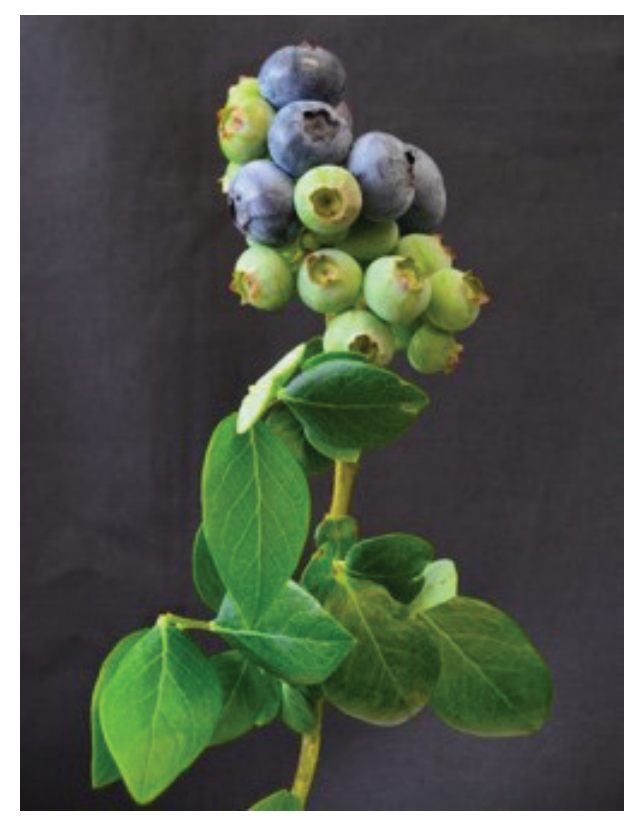

Figure 13. 'Arcadia'TM

Credits: UF Blueberry Breeding Program
'Avanti' ${ }^{\mathrm{TM}}$ (US Patent 26,312) (Figure 14) is a very earlyripening cultivar with a very low chill requirement, released by the University of Florida in 2015 . Yield potential in an evergreen system is above average. The fruit are firm and high quality with a small dry picking scar, although fruit can be smaller than some other cultivars, particularly late in the season. Susceptibility to Botrytis fruit rot and bacterial wilt has been reported, and research into the susceptibility of 'Avanti' 'тм to bacterial wilt is ongoing. Mite, thrips, and gall midge infestations have also been reported. Early bloom may require longer periods of freeze protection in certain regions.

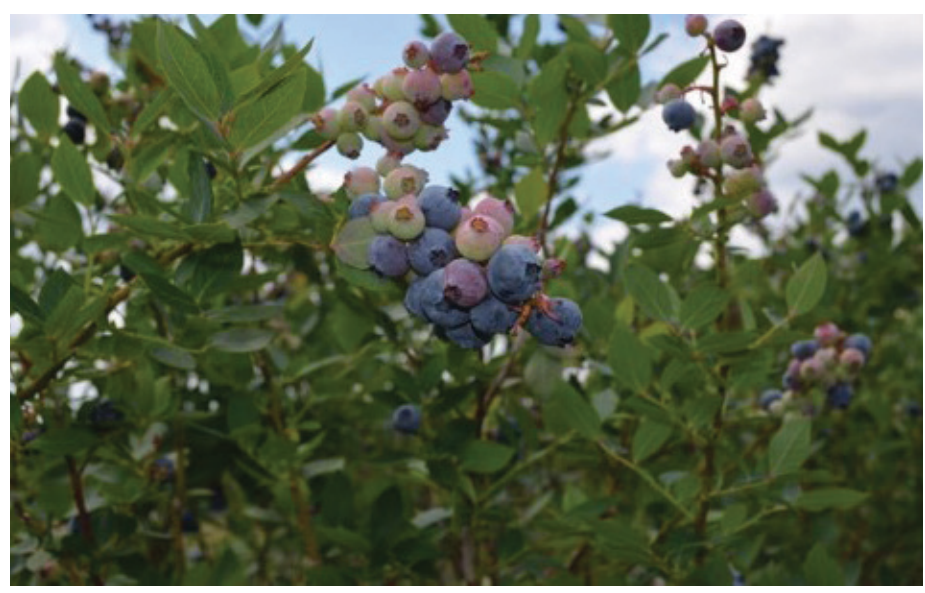

Figure 14. 'Avanti ${ }^{\mathrm{Tm}}$.

Credits: UF Blueberry Breeding Program

'Avanti' ${ }^{\text {тм }}$ is well suited for evergreen production in lowchill regions of central and south-central Florida, where fruit has ripened as early as late January.

'Endura' ${ }^{\mathrm{TM}}$ (US Patent Pending) (Figure 15) is a very lowchill, mid- to late-season cultivar released by the University of Florida in 2015. It produces well under both evergreen and hydrogen cyanamide management systems, with high season-long yield, although the harvest season can be very long in an evergreen system. Berries are large and firm, with excellent, persistent blue color. However, fruit can be tart early in the season. Some susceptibility to leaf rust and Phytophthora root rot has been reported.

'Endura' ${ }^{\text {тм }}$ is best adapted to central and south-central Florida.

'Indigocrisp' ${ }^{\mathrm{TM}}$ (US Plant Patent 26,523) (Figure 16) is an early-ripening cultivar released by the University of Florida in 2013. It has excellent field survival and leaf disease tolerance under optimal conditions. Berries are very firm with a crisp texture, and have a very high sugar:acid ratio. 'Indigocrisp' ${ }^{\text {TM }}$ leafs out well, ripens earlier, and has higher yield potential than other crisp-textured cultivars. 
'Indigocrisp ${ }^{\text {TM }}$ shows above average potential for machine harvest for the fresh market. It has shown some susceptibility to stem blight. This variety has low survival in areas with long-term standing water, so these areas should be avoided.

Due to somewhat higher chilling requirements, 'Indigocrisp $^{\text {'TM }}$ appears best adapted to regions with chilling similar to or greater than Gainesville, Florida.

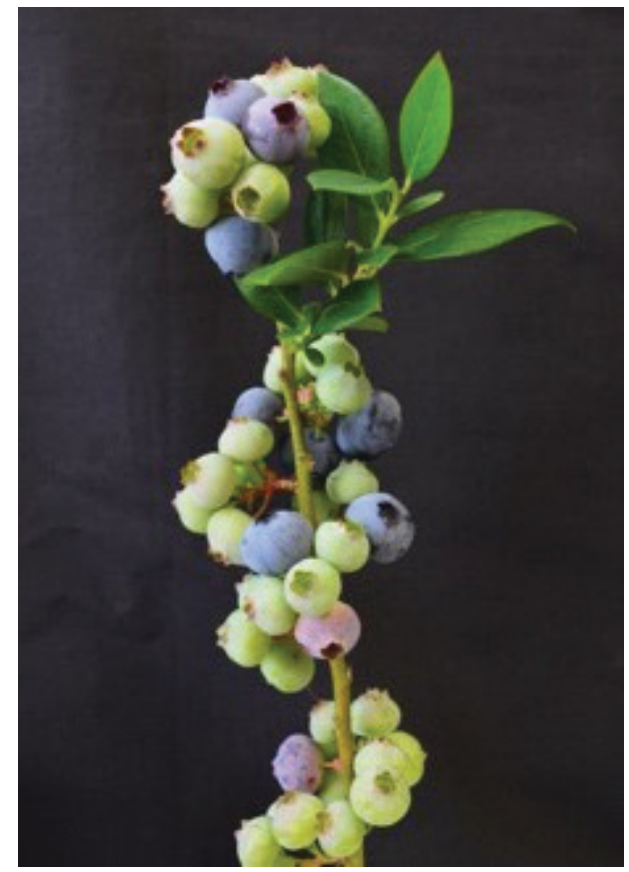

Figure 15. 'Endura' ${ }^{\prime \mathrm{TM}}$.

Credits: UF Blueberry Breeding Program

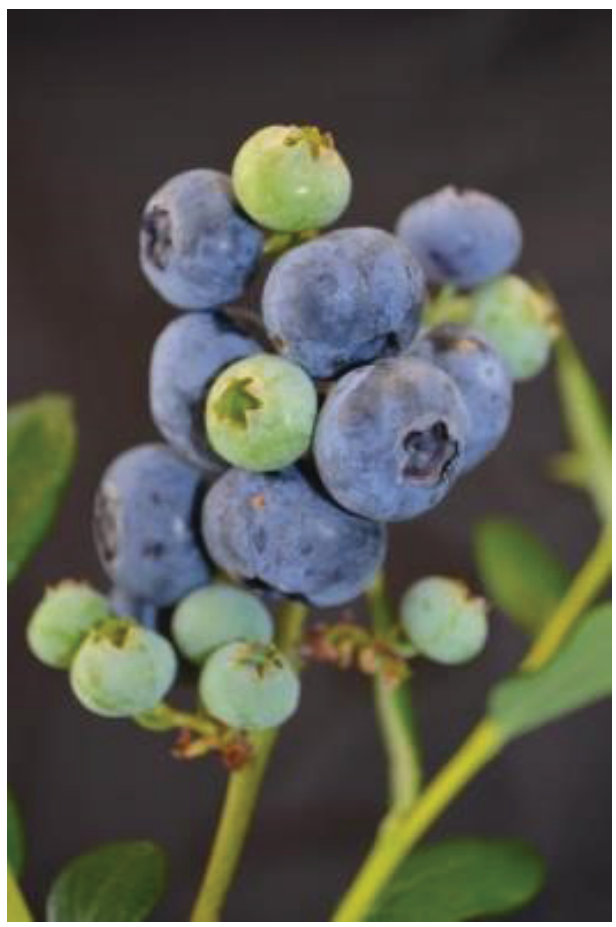

Figure 16. 'Indigocrisp ${ }^{\prime T M}$.

Credits: UF Blueberry Breeding Program
'Keecrisp' ${ }^{{ }_{\mathrm{TM}}}$ (US Patent 27,771) (Figure 17) is a mid- to late-season cultivar released by the University of Florida in 2016. It has an upright architecture and a high yield when it receives sufficient chilling, and it is best adapted to a hydrogen cyanamide management system. Leafing can be delayed, even with hydrogen cyanamide application. Berries are crisp with a small dry picking scar, although coloring at the stem end can be uneven. 'Keecrisp' ${ }^{\text {TM }}$ has demonstrated suitability for machine harvesting for freshmarket production.

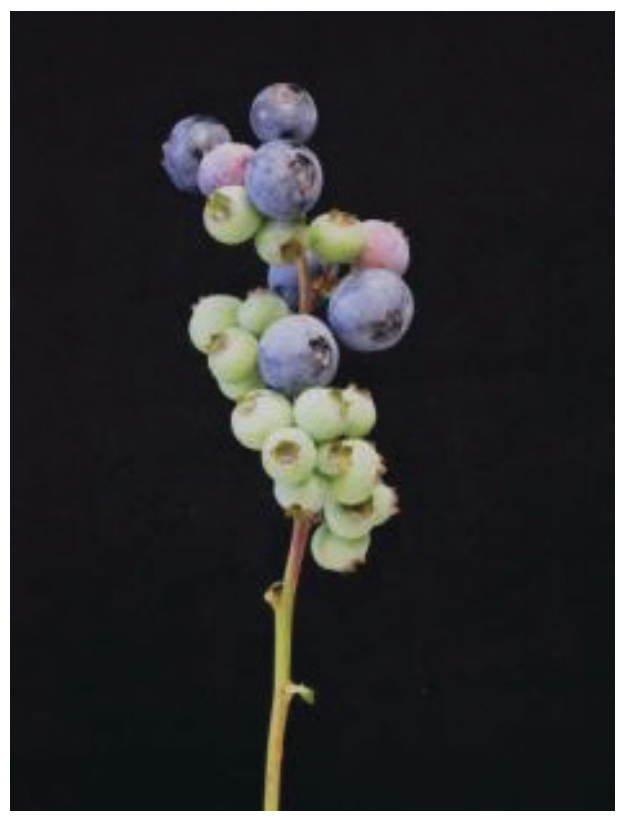

Figure 17. 'Keecrisp' ${ }^{\text {TM }}$.

Credits: UF Blueberry Breeding Program

Due to a somewhat higher chilling requirement,

'Keecrisp' ${ }^{\mathrm{TM}}$ is best adapted to areas with chilling similar to Gainesville or higher.

'Patrecia' (US Patent 27,740) (Figure 18) is an early- to mid-maturing cultivar released by the University of Florida in 2016. It has an upright architecture and a high yield with adequate chilling. Late blooming allows less freeze protection when compared to other cultivars. It has very uniform ripening. Berries are large but have a larger-than-desired picking scar that can tear during harvest if not careful. The fruit cluster is tight, requiring hand harvesting, and is not recommended for machine harvesting (using current machine technology). This cultivar benefits from and produces best with a hydrogen cyanamide management system.

Due to a somewhat higher chilling requirement, 'Patrecia' is best adapted to north-central Florida. 


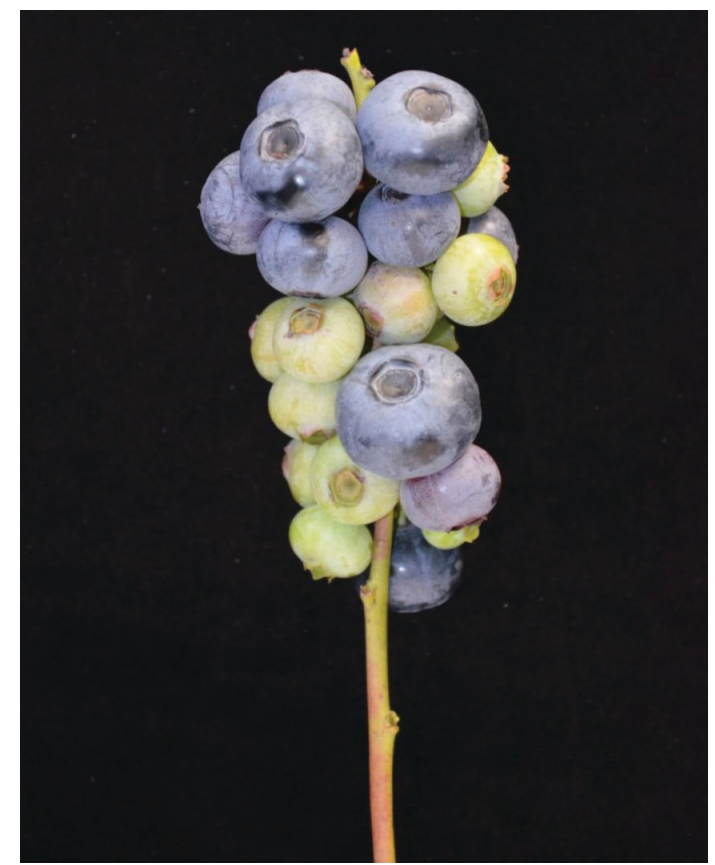

Figure 18. 'Patrecia'.

Credits: UF Blueberry Breeding Program

\section{Cultivars Recently Released}

Three cultivars were approved in 2017 for release from the University of Florida and are expected to be available for license to nurseries in 2018 (Plant Patents applied for). The same precautions noted for "New Cultivars" should be considered for these cultivars.

'Magnus' (FL04-213) (Figure 19) is an early-maturing cultivar for hand harvest during the Florida window for the fresh-fruit market. It is very consistent across seasons and has been successful in both hydrogen cyanamide and non-hydrogen cyanamide production systems. However, if hydrogen cyanamide is used in production, only very low doses are recommended. The fruit is large (similar to 'Emerald'), although not considered firm enough for machine harvesting. It is less vigorous than 'Emerald' and may require freeze protection in January.

Due to somewhat higher chilling requirements, 'Magnus' may be best adapted to the north-central Florida region; additional field data in central and south-central Florida is being collected.

'Optimus' (FL08-262) (Figure 20) is an early-maturing cultivar suitable for machine harvest for the fresh market. Berries are firm, medium sized, and high quality; the bush has good natural leafing. No or very low doses of hydrogen cyanamide are recommended because high damage with traditional doses has been observed. Some chilli thrips damage has been observed in the summer, but no reduction in yield has been observed. 'Optimus' may require freeze protection in January.

'Optimus' has produced well across all of Florida, with the best production in north Florida.

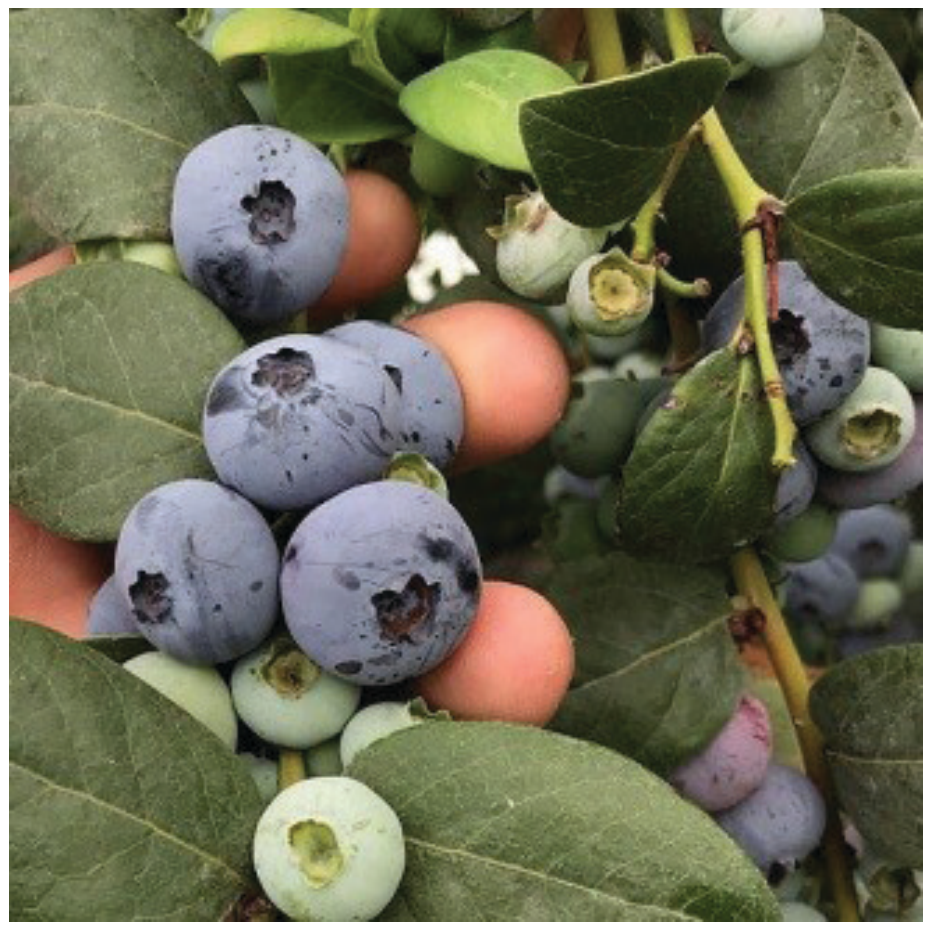

Figure 19. 'Magnus'.

Credits: UF Blueberry Breeding Program

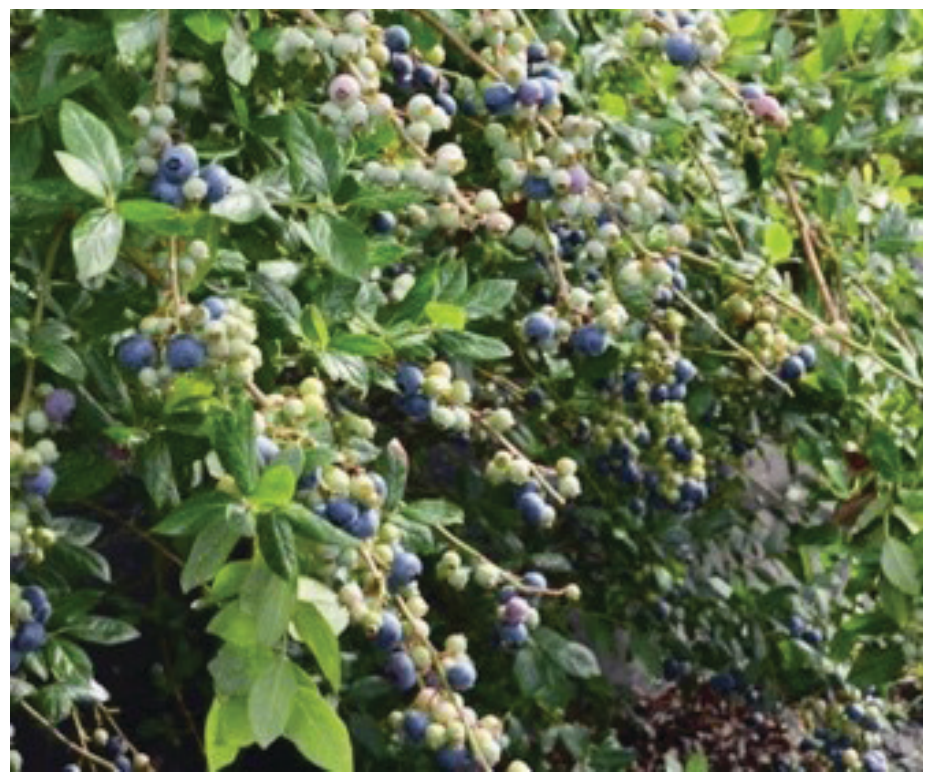

Figure 20. 'Optimus'.

Credits: UF Blueberry Breeding Program

'Wayne' (FL06-354) (Figure 21) is an early-maturing cultivar with high yields. Fruit is similar to 'Jewel' but firmer on average with earlier production-two weeks earlier than 'Jewel' when no hydrogen cyanamide is used. 'Wayne' has similar yield potential as 'Jewel'. Low doses 
of hydrogen cyanamide are recommended. Similar leaf diseases as 'Jewel' have been observed.

Due to somewhat higher chilling requirements, 'Wayne' may be best adapted to the north-central Florida region; additional field data in central and south-central Florida is being collected.

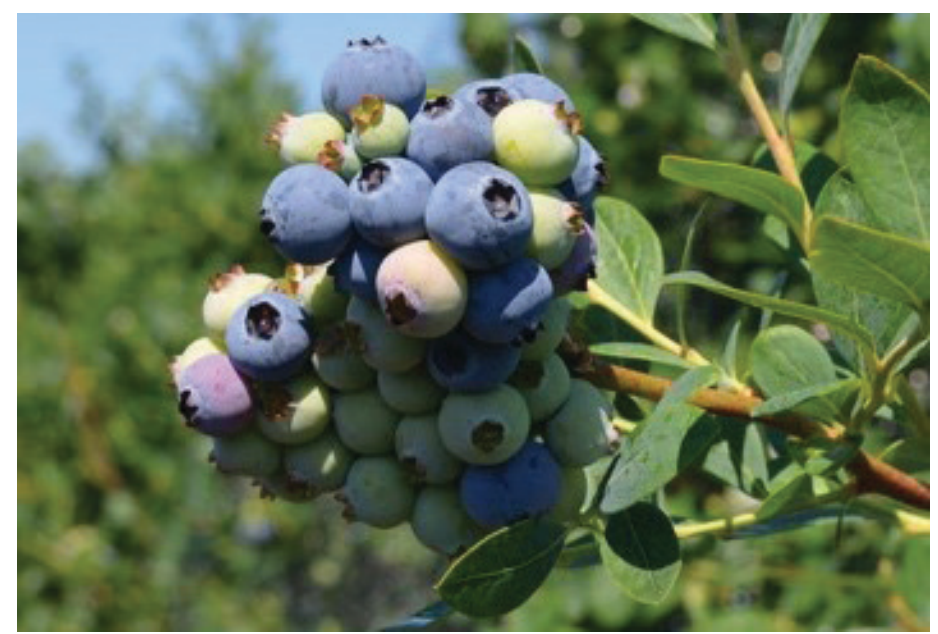

Figure 21. 'Wayne'.

Credits: UF Blueberry Breeding Program

\section{Historical and Obsolete Cultivars}

These cultivars were previously planted in Florida but are no longer recommended for commercial production.

'Star' (US Plant Patent 10,675) (Figure 22) was released by the University of Florida as a patented cultivar in 1995. Since its release, 'Star' has been widely planted in the northern production areas of Florida and in southeast Georgia. 'Star' has a slightly higher chill requirement than most other cultivars grown in Florida, and it is less likely to bloom in January or early February. In Alachua County, the average date on which 'Star' reaches $50 \%$ bloom is February 23. The first half of the crop is normally ripe by April 26.

'Star' leafs well in Gainesville and southeastern Georgia but is less vigorous and smaller in stature than many cultivars. 'Star' has a very short bloom-to-ripe interval and has a relatively compressed harvest season of about three weeks. Berries are easy to harvest by hand, and the quality is excellent with regards to size, firmness, and scar. Due to its slightly higher-than-average chill requirement, 'Star' is best adapted to north Florida and southeastern Georgia. 'Star' has not performed well south of Ocala, Florida, where it tends to produce few flowers and has weak growth.

Note: Although 'Star' has historically been a major cultivar for Florida and south Georgia, its ability to survive in the field has come into question due to a high incidence of bacterial leaf scorch (Figure 23) caused by the bacterium
Xylella fastidiosa and its apparent susceptibility to blueberry necrotic ring blotch virus (Figure 24). Due to marginal yields and a high incidence of bacterial leaf scorch, 'Star' is no longer recommended for new plantings in Florida.

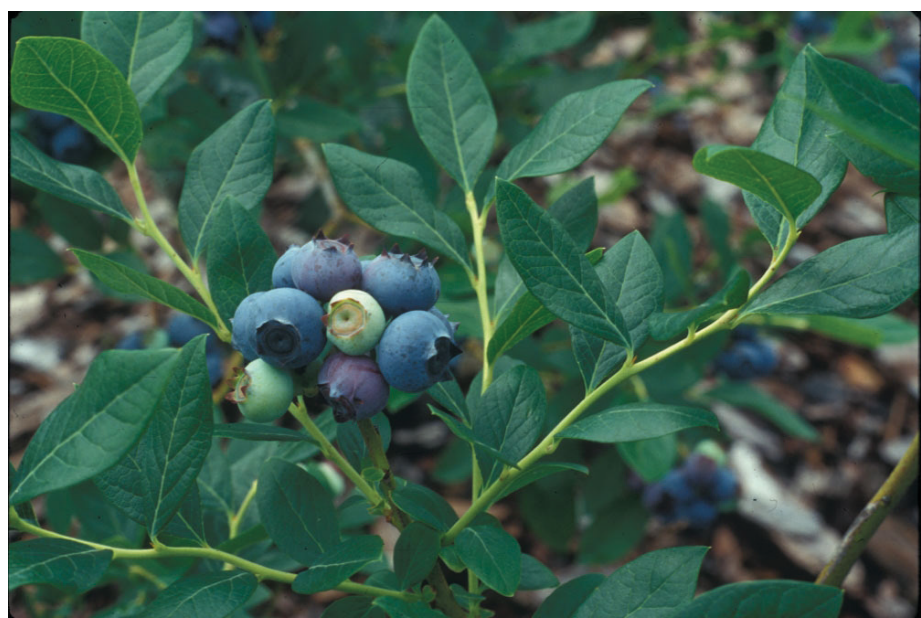

Figure 22. 'Star'.

Credits: Jeff Williamson, UF/IFAS

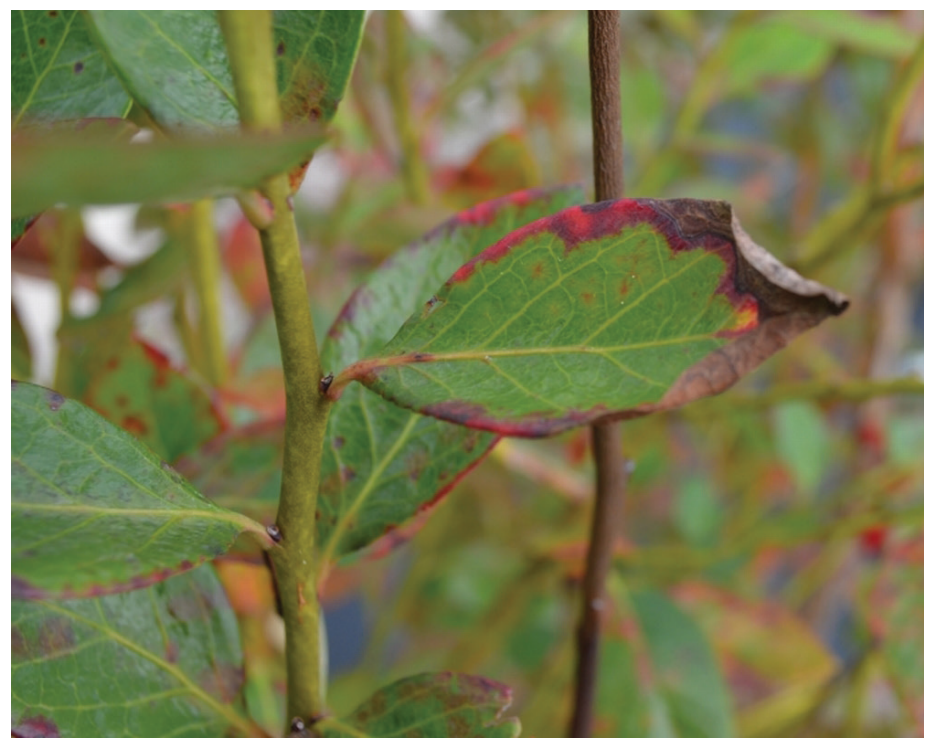

Figure 23. 'Star' showing symptoms of bacterial leaf scorch. Credits: Jim Olmstead, UF/IFAS

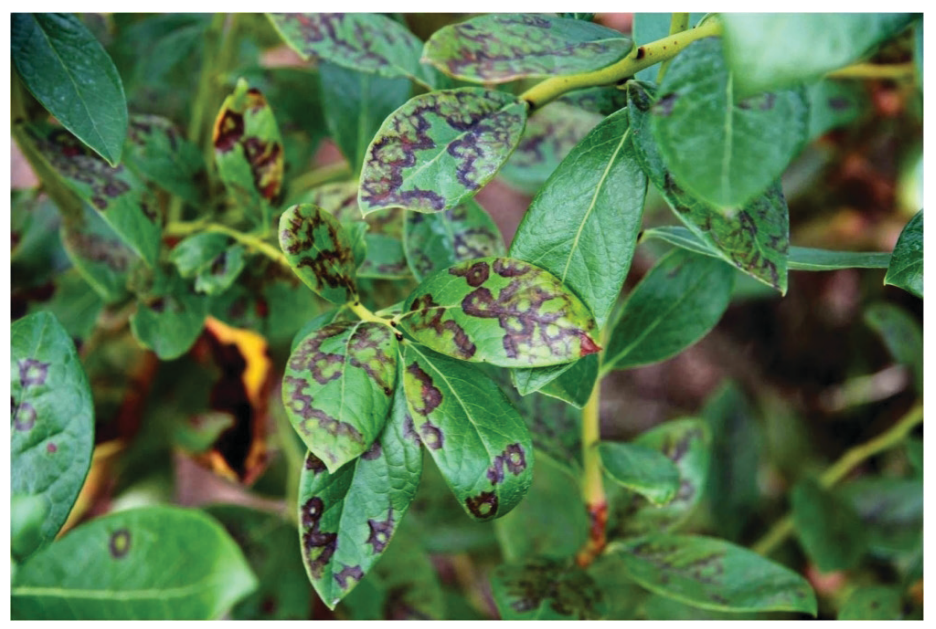

Figure 24. 'Star' showing symptoms of necrotic ring blotch. Credits: Jim Olmstead, UF/IFAS 
'Flicker' ${ }^{\mathrm{TM}_{\mathrm{M}}}$ (US Plant Patent 21,554) (Figure 25) was released by the University of Florida in 2009. 'Flicker'TM is a vigorous, upright-to-spreading plant with potential for evergreen production in central and south-central Florida and deciduous production as far north as Gainesville, Florida. The mean dates for 50\% open flowers and 50\% ripe berries in Windsor, Florida, are February 3 and April 30, respectively. Early harvest in central Florida can be achieved by growing in an evergreen management system. However, production in this manner results in an extended harvest season, often lasting from early March through May. High vigor enables 'Flicker' ${ }^{\text {тM }}$ to carry a heavy crop, although there have been reports of poor young-plant establishment from liners. The reason for this is still unknown, but 'Flicker ${ }^{\mathrm{TM}}$ ' may not tolerate "wet feet" well or may be more susceptible to Phytophthora root rot than many southern highbush cultivars. Berries are large, light blue, and in loose clusters that are easy to harvest by hand. Berries are firm with good flavor and a dry picking scar. Berries tend to retain their quality for an extended period while on the bush.

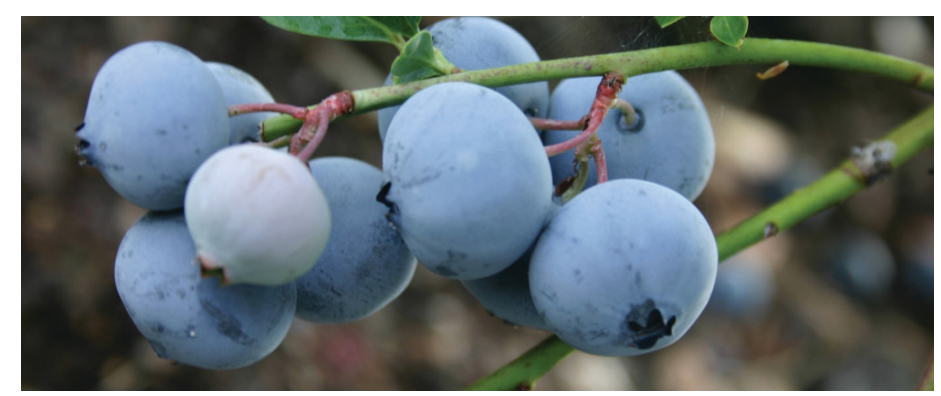

Figure 25. 'Flicker'TM

Credits: Jim Olmstead, UF/IFAS

Note: Although 'Flicker'тм was historically a major cultivar for evergreen production in central Florida, its ability to survive in the field has come into question due to a high incidence of a stem lesion form of anthracnose. Accordingly, 'Flicker'тм is no longer recommended for new plantings in Florida.

'Windsor' (US Plant Patent 12,783) was released by the University of Florida in 2000 (Figure 26). It is vigorous, with stout stems and a semi-spreading growth habit. In Alachua County, the mean date of $50 \%$ open flowers is February 23. 'Windsor' leafs out strongly as it begins to flower, and this strong leafing enables it to support a large crop. The average date for the first commercial hand harvest of 'Windsor' in Alachua County is April 15, and $50 \%$ of the berries are normally ripe by April 28. 'Windsor' berries are very large, especially early in the harvest season. Berries from the first half of the harvest average about 2.4 grams on young vigorous plants. Berry color is similar to
'Star', and the berries are firm and have excellent flavor. Although 'Windsor' grows and fruits well, it has lost favor among growers because of the deep picking scar that can tear at harvest, which can increase packing costs and reduce postharvest fruit quality. There have been reports of greater-than-average susceptibility of 'Windsor' to hydrogen cyanamide injury. Because of these limitations, 'Windsor' is not widely grown in Florida.

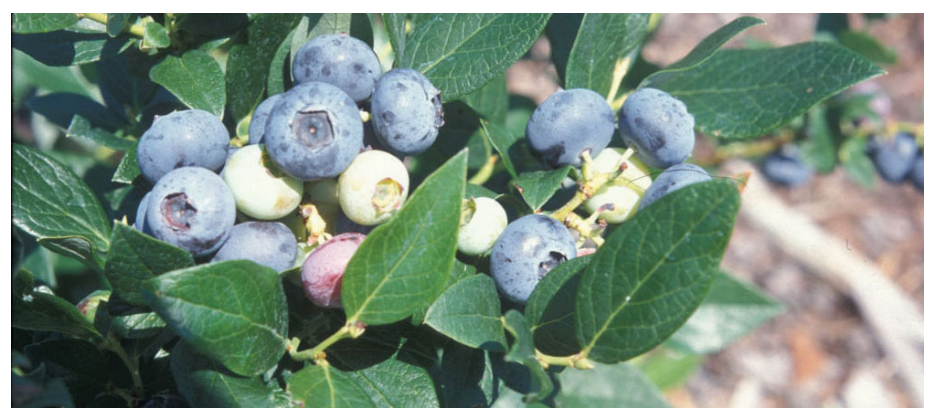

Figure 26. 'Windsor'.

Credits: Jeff Williamson, UF/IFAS

'Scintilla' (US Plant Patent 19,233) (Figure 27) was released by the University of Florida in 2007. It is a vigorous, semiupright plant that produces a medium yield of large berries with excellent color, scar, firmness, and flavor. The berries are in loose clusters and easily harvested by hand. 'Scintilla' has a longer fruit development period, as it typically blooms before 'Star', while its harvest is considered mid-season in Florida. 'Scintilla' appears to have above-average susceptibility to Phytophthora root rot, leaf spots, and anthracnose, and its long-term field survival has been below average in numerous situations. 'Scintilla' is not widely grown in Florida.

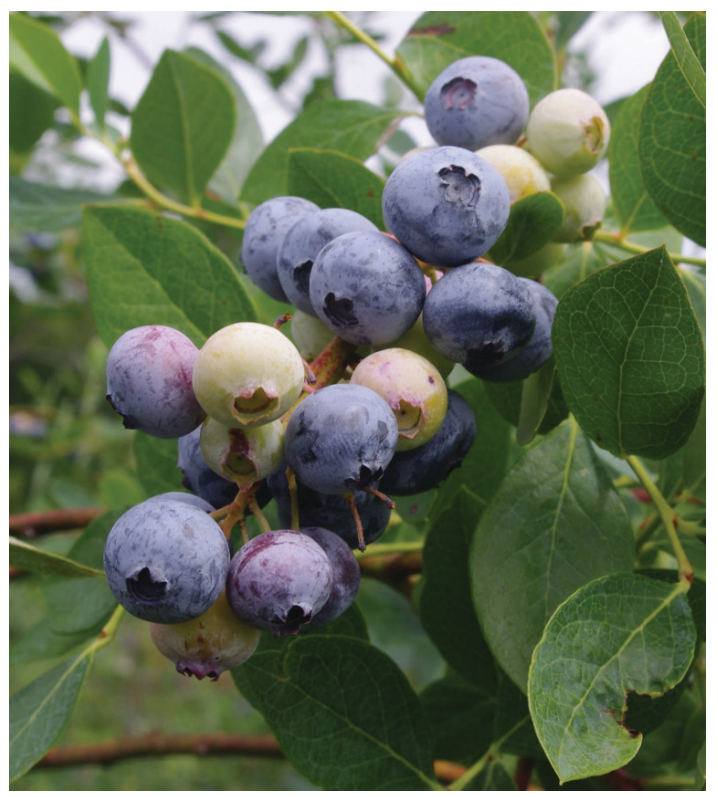

Figure 27. 'Scintilla'.

Credits: Jim Olmstead, UF/IFAS 


\section{Other Potential Cultivars}

Blueberry production, especially in areas where southern highbush blueberries will be grown, has followed the same pattern of rapid expansion since the early 2000s that has been seen in Florida. As a result, there has been an increase in the number of blueberry breeding programs, both public and private, that are developing southern highbush blueberry cultivars. In the southeastern United States, blueberry breeding programs at the University of Georgia, North Carolina State University, the University of Arkansas, the United States Department of Agriculture Agricultural Research Service (Poplarville, Mississippi, and Beltsville, Maryland), as well as Fall Creek Farm and Nursery in the Pacific Northwest (Lowell, Oregon) have all developed southern highbush blueberry cultivars. None of the cultivars from these other programs are grown in significant acreage in Florida at this time. Typically, the cultivars developed at these breeding programs have not had a low enough chilling requirement for Florida production. Likewise, there is a lengthy list of southern highbush blueberry cultivars released from UF/IFAS that are no longer widely grown.

\section{Patented Cultivars: Legal Requirements}

The blueberry breeding program at the University of Florida is financed to a large extent by revenues from royalty payments on patented cultivars. The newer cultivars developed by this program are patented. Propagation of these cultivars requires a license from the agency holding the patent. Planting a patented cultivar does not require a license if the plant was purchased from a licensed propagator, but it is always important to retain the documentation you receive from a licensed nursery indicating the plants were legally obtained. Propagation of patented cultivars without a license is a violation of the law, even if you own the plants from which the cuttings are taken. To inquire about licenses for UF/IFAS cultivars, contact Florida Foundation Seed Producers, Inc., PO Box 110200, Gainesville, FL 32611-0200; phone (352) 273-3656; e-mail jwatson@ffsp.net. 
Table 1. Characteristics of selected southern highbush blueberry cultivars.

\begin{tabular}{|c|c|c|c|c|c|c|c|c|c|c|}
\hline \multirow[b]{2}{*}{ Cultivar } & \multicolumn{4}{|c|}{ Plant Characteristics } & \multicolumn{6}{|c|}{ Berry Characteristics } \\
\hline & Vigor & Flowering & $\begin{array}{c}\text { Yield } \\
\text { Potential } \\
\text { C/N }\end{array}$ & Season & $\begin{array}{l}\text { Size } \\
(\mathrm{mm})\end{array}$ & Scar & $\begin{array}{l}\text { Firmness } \\
(\mathrm{g} / \mathrm{mm})\end{array}$ & BRIX & TTA & Shelf Life \\
\hline 'Arcadia'TM & High & Mid & $9 / 6$ & Mid & 20 & & 179 & 10.9 & 0.49 & \\
\hline 'Avanti' & Med & Early & $7 / 6$ & Early & 22 & 9 & 214 & 12.4 & 0.34 & \\
\hline 'Chickadee 'TM & Med & Early & $7 / 6$ & Early & 20 & 9 & 238 & 11.6 & 0.24 & Excellent \\
\hline 'Emerald' & Med-High & Mid/early & $9 / 9$ & Mid/late & 23 & 9 & 197 & 11.2 & 0.53 & Good \\
\hline 'Endura'TM & Med & Mid/early & $8 / 6$ & Mid/late & 25 & & 230 & 10.6 & 0.45 & \\
\hline 'Farthing' & Med-Low & Mid/late & $7 / 8$ & Mid/late & 22 & 9 & 229 & 10.9 & 0.36 & Excellent \\
\hline Indigocrisp ${ }^{\prime \mathrm{TM}}$ & Low & Mid & $4 / 6$ & Mid/late & 26 & & 246 & 11.5 & 0.29 & \\
\hline 'Jewel' & High & Mid/early & $7 / 8$ & Mid & 20 & 9 & 182 & 11.0 & 0.42 & Good \\
\hline${ }^{\prime K e e c r i s p}{ }^{\prime T M} *$ & & & $* / 6$ & Mid/late & 19 & & 262 & 11.7 & 0.18 & \\
\hline 'Kestrel' & Med-High & Early & $6 / 5$ & Early & 21 & 8 & 200 & 11.8 & 0.43 & Excellent \\
\hline 'Magnus' * & Med & Early & $* / 8$ & Early & 20 & & 181 & 10.2 & 0.64 & \\
\hline${ }^{\prime} M e a d o w l a r k ' T M$ & High & Early & $7 / 8$ & Mid/Early & 22 & 8 & 239 & 10.8 & 0.24 & Excellent \\
\hline 'Optimus'* & High & Mid/early & $7 / 7$ & Mid/early & 16 & & 223 & 11.7 & 0.41 & \\
\hline 'Patrecia'* & & Mid/late & $5 / 9$ & Mid/late & 20 & & 220 & 10.9 & 0.34 & \\
\hline 'Primadonna' & High & Mid/early & $6 / 6$ & Early & 25 & 8 & 212 & 12.2 & 0.35 & Excellent \\
\hline 'Raven'TM & Med-High & Mid & $5 / 5$ & Mid/late & 26 & 7 & 277 & 12.0 & 0.23 & Larger scar \\
\hline 'Scintilla' & Med & Early & $6 / 5$ & Early/mid & 28 & 9 & 217 & 12.4 & 0.55 & Excellent \\
\hline 'Snowchaser' & Med & Early & $6 / 7$ & Very early & 16 & 8 & 192 & 12.8 & 0.32 & Good \\
\hline 'Springhigh' & High & Early & $7 / 8$ & Early & 23 & 8 & 194 & 10.7 & 0.28 & $\begin{array}{l}\text { Soft in hot } \\
\text { weather }\end{array}$ \\
\hline 'Sweetcrisp' & High & Mid & $3 / 5$ & Mid & 22 & 9 & 277 & 13.7 & 0.47 & Excellent \\
\hline 'Wayne'* & & Mid/early & $* / 8$ & Early & 18 & & 167 & 11.8 & 0.22 & \\
\hline
\end{tabular}

